Д.А. Гриб, Б.О. Демідов, О.О. Хмелевська, С.І. Хмелевський

Харківський національний університет Повітряних Сил ім. І. Кожедуба, Харків

\title{
МЕТОДИЧНІ І ОРГАНІЗАЦІЙНІ АСПЕКТИ ПРОГРАМНО-СИТУАЦІЙНОГО УПРАВЛІННЯ РОЗВИТКОМ СИСТЕМИ ОЗБРОЄННЯ ЗБРОЙНИХ СИЛ
}

У статті розглядаються проблемні питання, щзо пов'язані з використанням принципів і положень програмно-ситуаційного підходу до вирішення задач управління розвитком системи озброєння збройних сил держави у програмному періоді часу. Основна увага приділяється скоординованому використанню стратегічного програмно-цільового планування і програмно-ситуачійного підходу до оперативного управління вирішенням проблемних ситуацій в умовах невизначеності і недостатності вихідних даних, шяо необхідні для адекватного і адаптивного реагування на зміни зовнішнього середовища (оперативно-стратегічної, воєнноекономічної, виробничо-технологічної та іншої обстановки). Аналізуються відмінності програмноситуаційного і програмно-иільового підходу для оперативного планування заходів з протидї негативним тенденціям розвитку системи озброєння. Указується на доцільність використання орієнтованих графів для створення моделей проблемних ситуаџій розвитку системи озброєння та окремих ї̈ складових на довгостроковий період.

Ключові слова: система озброєння збройних сил, проблемна ситуація, ситуаційний аналіз, модель проблемної ситуації, сценарій розвитку проблемної ситуації, резерви ресурсів.

\section{Вступ}

Постановка проблеми. Управління розвитком системи озброєння (СО) збройних сил здійснюється на декількох взаємопов'язаних етапах: довгострокового (стратегічного) планування, корекції стратегічного плану на основі формування оперативних планів, оперативного управління [1].

Складність стратегічного (довгострокового) планування пов'язана із певною невизначеністю в отриманні оцінок безпекового (операційного) середовища на довгостроковому періоді до 20-30 років.
На етапі стратегічного планування здійснюється обгрунтування комплексу організаційних, науковотехнічних, економічних та інших заходів, що забезпечують підтримання потрібного стану СО, прогнозування ризиків невиконання заходів плану, формування збалансованих потреб ресурсів, визначення виконавців і термінів виконання стратегічного плану розвитку СО. На різних етапах стратегічного планування (табл. 1) прогнозується динаміка змін обсягу витрат на утримання, розвиток і забезпечення СО на протязі життєвих циклі (ЖЦ) складових СО і усіх зразків ОВТ СО на довгостроковому періоді [1-2].

Таблиця 1

Етапи стратегічного планування

\begin{tabular}{|l|l|}
\hline \multicolumn{1}{|c|}{ Етапи } & \multicolumn{1}{|c|}{ Основні результати етапу } \\
\hline $\begin{array}{l}\text { 1 - Розробка системи } \\
\text { вихідних даних }\end{array}$ & Оперативно-стратегічні, воєнно-технічні і техніко-економічні дані \\
\hline $\begin{array}{l}2 \text { - Оцінювання стану } \\
\text { системи озброєння }\end{array}$ & $\begin{array}{l}\text { Оцінки укомплектованості, технічної готовності, залишку технічного ре- } \\
\text { сурсу, оснащеності, потреб у ремонті і технічному обслуговуванні }\end{array}$ \\
\hline $\begin{array}{l}\text { д- Синтез вимог } \\
\text { до системи озброєння }\end{array}$ & $\begin{array}{l}\text { Система цілей розвитку ОВТ, їх декомпозиція до задач воєнно-технічних } \\
\text { систем, визначення пропорцій фінансування видів і типів ОВТ }\end{array}$ \\
\hline $\begin{array}{l}\text { 4- Визначення шляхів } \\
\text { реалізації вимог }\end{array}$ & $\begin{array}{l}\text { Формування вихідної множини зразків ОВТ до стратегічного плану, оцін- } \\
\text { ки ресурсоємності і ресурсозабезпеченості задач }\end{array}$ \\
\hline $\begin{array}{l}5-\text { Формування множини } \\
\text { варіантів плану }\end{array}$ & $\begin{array}{l}\text { Варіанти стратегічного плану для різних обсягів фінансування. Прогноз } \\
\text { обсягів фінансування. Оцінки ефективності планових рішень. }\end{array}$ \\
\hline $\begin{array}{l}6-\text { Формування і вибір } \\
\text { раціональних варіантів }\end{array}$ & $\begin{array}{l}\text { Варіанти стратегічного плану для уточненого обсягу фінансування. Воєн- } \\
\text { но-технічні і техніко-економічні оцінки варіантів }\end{array}$ \\
\hline $\begin{array}{l}\text { п- Формування } \\
\text { підсумкового проєкту плану }\end{array}$ & $\begin{array}{l}\text { Проєкт стратегічного плану. Оцінювання реалізованості плану підприємс- } \\
\text { твами оборонно-промислового комплексу (ОПК) }\end{array}$ \\
\hline
\end{tabular}

Джерело: розроблено авторами за даними [1-2].

Ефективність управління розвитком СО у сучасних умовах залежить від досконалості методологічної бази, що забезпечує зменшення протиріч (розбіжностей) між глибиною стратегічного плануван- ня, макропоказниками програм і планів розвитку СО (державної цільової програми розвитку озброєнь, державного оборонного замовлення, державних контрактів) і практично отриманими їх значеннями на 
директивно (нормативно) встановлюваних інтервалах часу [3-4].

Для підвищення ефективності управління розвитком СО у сучасних умовах необхідно дотримуватись принципів і методичних положень ситуаційного підходу до управління [5-6]:

- формування сценаріїв розвитку проблемної ситуації, викриття закономірностей і тенденцій іiі розвитку;

- динамічності циклу управління (корекція програми управління у відповідності з прогнозом виникнення проблемної ситуації);

- резервування (компенсація збурень, що виникають, на основі оперативного формування резерву за рахунок внутрішніх ресурсів ЖЦ зразків ОВТ);

- превентивність (використання завчасно підготовлених варіантів вирішення можливих проблемних ситуацій);

- оперативність (виявлення і вирішення ризику прояву проблемної ситуації (у процесі її виникнення і розвитку) шляхом автоматизації вирішення ситуаційних задач в інтересах вирішення проблемної ситуації).

Технології управління розвитком СО на сучасному етапі мають забезпечувати формування управлінських рішень в умовах нестабільності у геополітичних, воєнних, економічних, соціальних, екологічних та інших зовнішніх факторів, розширення спектру факторів невизначеності (ризиків), що виникають, зміни динаміки і характеру процесів, що відбуваються, неповноти, неточності, фрагментарності, суперечності техніко-економічних вихідних даних для планування. Це призводить до низької достовірності результатів прогнозів умов реалізації програм і планів розвитку СО і стійкості планів.

Можливо пропонувати вирішувати задачі управління розвитком $\mathrm{CO}$ за двома складовими:

- вирішення планових задач на основі базових принципів і методів програмно-цільового планування [3];

- вирішення проблемних ситуацій, що $є$ наслідками важко прогнозованих критичних і кризових явищ у геополітичному, економічному, політикоправовому та інших просторах ситуаційних задач (у процесі реалізації програм і планів розвитку СО) як складних систем воєнного призначення на основі методів і моделей, що характерні для програмноситуаційного управління [7-9].

Слід зазначити, що методи і моделі програмноситуаційного управління стосовно до проблематики розвитку СО опрацьовані недостатньо, але саме їх використання при реалізації програм і планів розвитку СО має забезпечити оперативне реагування i своєчасну адаптацію процесів управління до змін зовнішніх умов.

Це може розглядатись як суттєве доповнення до існуючих методів вирішення управлінських задач [5; 10], що використовуються в інтересах своєчасного вирішення проблемних ситуацій у процесі реалізації програм і планів розвитку СО.

Мета статті - представити основні сучасні організаційні і методичні принципи і положення програмно-ситуаційного підходу до оперативного управління розвитком СО при вирішенні проблемних ситуацій в умовах невизначеності і неповноти вихідних даних, прояву факторів ризику невиконання програм і плану розвитку СО у плановому періоді.

\section{Виклад основного матеріалу}

Систему озброєння збройних сил (3С) слід розглядати як доцільно організовану, адекватно підпорядковану їх задачам і структурі сукупність взаємно узгоджених і таких, що доповнюють один одного по функціях, що виконуються і тактико-технічним характеристикам (бойовим (функціональним) можливостям) зразків (комплексів, систем) ОВТ різних видів, типів і функціонального призначення (бойових засобів, засобів бойового управління, бойового i матеріально-технічного забезпечення), що призначені для забезпечення ефективного ведення операцій (бойових дій) збройних сил держави (угрупованнями військ (сил)) за єдиним командуванням i оперативним управлінням у особливий період і виконання ними своїх задач в умовах повсякденної діяльності, у миротворчих і інших операціях [7].

У сучасних умовах $\mathrm{CO}$ має розглядатись як складна багатокомпонентна i багатопараметрична система військового призначення з керованою структурною динамікою. При цьому під структурною динамікою (СД) слід розуміти процес зміни структури системи у часі під впливом факторів різного характеру, як керованих, так і не керованих. Процес управління СД можливо описати сукупністю контрольованих впливів керування і реалізації цілеспрямованих заходів, які забезпечують переведення поточного стану структури СО у потрібний стан у відповідності з динамікою зміни зовнішнього середовища (зовнішніх умов воєнного, економічного і іншого характеру) шляхом оперативного управління 3 урахуванням системного принципу підпорядкованості структури функціям СО [1].

У процесі управління розвитком СО і їі СД в умовах невизначеності і прояву факторів ризику у загальному вигляді вирішуються дві задачі:

- програмного управління, що використовує тільки ту множину початкових даних і прогнозовані значення їх змін, яка $\epsilon$ до початку управління, i розв'язується з використанням методів програмноцільового планування [1] у межах програми управління розвитком $\mathrm{CO}$;

- ситуаційного управління [8-9; 11-12], у якому використовуються уточнені вихідні дані $\{|b i|\}$ 
розвитку СО на короткострокових періодах планування ( $n$ - кількість періодів короткострокового планування) для оцінювання програми управління i прогнозування їх відхилень на наступний період.

На етапі стратегічного планування мають бути визначені: значення показників оцінювання розвитку СО у короткострокових періодах на протязі реалізації усього стратегічного плану, тим самим формується опорна траєкторія розвитку СО; періоди програмного управління, на протязі яких програма управління не змінюється; перелік параметрів, за якими буде проводитись аналіз необхідності змін траєкторії розвитку СО; граничні значення відхилень кожного з параметрів розвитку СО на протязі періоду програмного управління; модель розвитку
CO. Траєкторія розвитку СО може бути описана наступним виразом

$$
A(t)=F\left(\left\{\left|a_{i}\right|\right\},\left\{\left|\Delta a_{i}\right|\right\},\left\{\left|b_{i}\right|\right\},\left\{\left|\Delta b_{i}\right|\right\}, t, \Delta t_{n}, T\right) .
$$

Введення елементів ситуаційного управління може дозволяти перейти від технології програмного управління розвитком СО до комбінованої технології програмно-ситуаційного управління, яка найбільш адекватно відповідає сучасним умовам, тому що забезпечує оперативне реагування системи управління $\mathrm{i}$ iii своєчасну адаптацію до змінних умов у процесі реалізації програм і планів розвитку СО. Узагальнена структурна схема програмно-ситуаційного управління розвитком СО приведена на рис. 1.

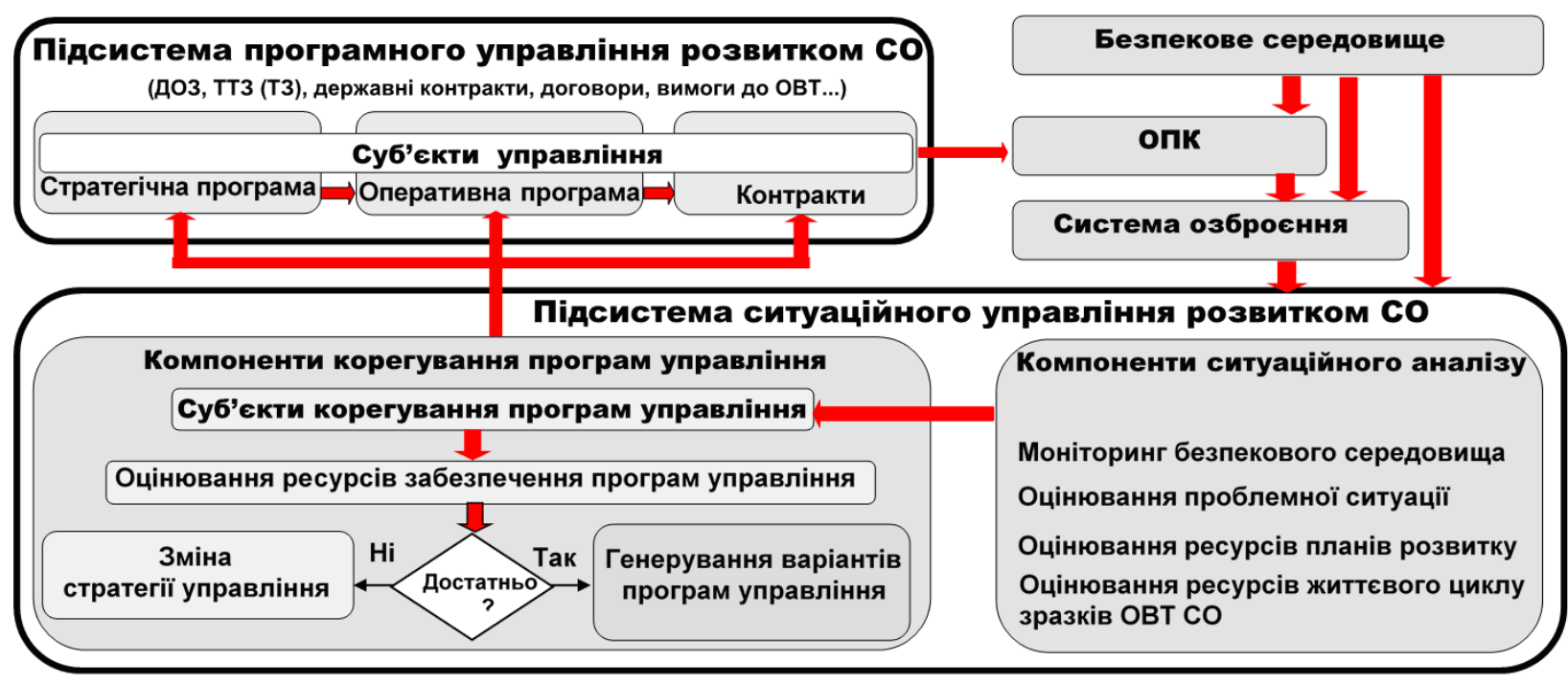

Рис. 1. Узагальнена структурна схема

програмно-ситуаційного управління розвитком системи озброєння (CO)

Джерело: розроблено авторами.

Питанням формалізації процесів управління розвитком складних наукоємних проєктів приділяється значна увага вітчизняних і закордонних науковців у тому числі і розробці нових і вдосконаленню існуючих методів ситуаційного і програмноситуаційного управління [13-14].

Ситуаційний підхід при стратегічному управлінні розвитком СО будується на оцінці довгострокової ситуації розвитку операційного середовища i організації оборонно-промислового комплексу (ОПК) держави для досягнення максимального бойового потенціалу 3С.

Критерієм оцінювання успішності управління розвитком СО у конкретній ситуації може бути гармонізація управлінських дій, при мінімумі конфліктів у процесі координації дій виконавців щодо вирішення проблемної ситуації [14].

Оптимізацію управлінських дій забезпечує проектний менеджмент на основі управління проектами [15]. Проектний підхід об'єднує елементи ситуаційного і процесного управління. Суть проектного підходу у процесі створення багатовартісних нау- коємних зразків ОВТ полягає у визначенні кінцевих і проміжних цілей (етапів) виконання великого обсягу робіт кооперацією багатьох підприємств для створення унікальних малосерійних зразків ОВТ, в умовах ризикованої рентабельності партії зразків ОВТ у середньостроковій і довгостроковій перспективах.

Проектний підхід дозволяє розподілити між усіма учасниками кооперації проекту відповідальність за результат кожного етапу, сформувати комплексну програму дій і зменшити ризики невиконання проекту [15-17].

У дослідженнях ЦНДІ ОВТ ЗС України [3] виділяються групи показників, які можливо використовувати при оцінюванні ефективності проекту, разом 3 цим слід зазначити, що динаміка змін значень показників і їх впливу на результат виконання проекту різні на протязі періоду його виконання. Вибір сукупності показників оцінювання ефективності реалізації проекту необхідно здійснювати на етапі обгрунтування його необхідності і визначену множину не змінювати на протязі усього ЖЦ проекту. 
Контроль i аналіз значень показників $\left\{\left|\Delta c_{i}\right|\right\},\left\{\left|\Delta a_{i}\right|\right\},\left\{\left|a_{i}\right|\right\},\left\{\left|b_{i}\right|\right\},\left\{\left|\Delta b_{i}\right|\right\}$ потребує розвитку процесів автоматизації проектування і контролю виконання проєктів усіма їх замовниками і виконавцями на протязі усього ЖЦ проєкту, для чого необхідні мережеві моделі проектування і супроводження проєктів СО [1; 18].

Ситуаційний підхід потребує мислення про організаційні проблеми, поєднання конкретних прийомів і концепції з певними конкретними ситуаціями, використання ситуаційних відмінностей між організаціями і всередині них [11-12].

3 урахуванням результатів досліджень [12] можливо запропонувати за ситуацією створення СО розуміти - усвідомлені знання органів державного (військового) управління про динаміку безпекового середовища, що представлені результатами об'єктивних досліджень та є основою для побудови обгрунтованої інтерпретації послідовності зміни станів (структурної динаміки) СО на довготривалому періоді.

Ситуаційне управління - метод управління на основі використання множини концепцій, моделей, доступних технологій для розпізнавання, пояснення, впливу і передбачення ситуацій, які виникли або можуть виникнути у динамічних системах на протязі наперед визначеного часу роботи [12].

Ситуаційне управління і проєктна діяльність реалізуються в етапах: ініціювання, планування, виконання, моніторингу і контролю та закриття проекту.

Ситуаційне управління має реалізовуватись для забезпечення траєкторії стратегічного розвитку СО в умовах невизначеності розвитку безпекового середовища шляхом зміни стану системи управління розвитком СО. Недосконалість ситуаційного управління призводить до несвоєчасного розпізнавання невизначеності ситуації, непрогнозованих обмежень запланованих ресурсів для ефективного розвитку СО на прогнозованому періоді. Автори досліджень [11] зазначають, що недосконалість ситуаційного управління призводить до того, що значна кількість підприємств ОПК України втрачає свій потенціал.

Узагальнена структурна схема етапів планування програмно-ситуаційного управління розвитком СО відображена на рис. 2.

Оцінювання стану СО на початок програмного періоду (кількісно-якісний стан $\mathrm{CO}$, потреби у ремонті зразків ОВТ, іiї відповідність сучасним вимогам і тощо) має дозволити визначити обсяг асигнувань, що необхідно виділяти на розвиток СО. У процесі оцінювання мають бути уточнені:

- укомплектованість (по кількості і номенклатурі) організаційно-штатних формувань ЗС основними видами і типами зразків (комплексів систем) ОВТ;

- забезпеченість військ (сил) сучасними зразками OBT;
- технічна готовність (справність) зразків ОВТ, що знаходяться у військах (силах), залишок їх технічного ресурсу, забезпеченість боєприпасами;

- оснащеність і стан технічних засобів автоматизації пунктів управління (командних пунктів);

- запаси воєнно-технічного майна по основних його видах;

- потреба у проведенні капітального ремонту ОВТ СО та різних видах технічного обслуговування і тощо.

При формуванні вимог до СО на завершення програмного періоду необхідно визначити, які задачі нею мають вирішуватись, 3 якою ефективністю, яким має бути рівень технічної оснащеності організаційно-штатних формувань 3С і тощо. Мають бути визначені доцільні шляхи реалізації вимог, що висуваються до СO, і сформована вихідна множина зразків ОВТ, яка буде включена у стратегічний план при різних рівнях фінансування на основі результатів прогнозування обсягів асигнувань.

Програмно-ситуаційний підхід до управління розвитком СО на відміну від програмно-цільового підходу має грунтуватись на своєчасному випередженні виникнення проблемних ситуацій, оперативному плануванні відповідних заходів 3 протидії негативним тенденціям розвитку ситуації і зниження їх негативного впливу на процес розвитку СО.

Для реалізації програмно-ситуаційного підходу необхідно мати методи ситуаційного аналізу, що зорієнтовані на виявлення факторів ризику виникнення проблемних ситуацій, формування можливих сценаріїв розвитку ситуації, оцінювання можливих втрат внаслідок їх виникнення. Методи вирішення проблемних ситуацій у процесі оперативного управління реалізацією програм і планів розвитку СО мають грунтуватись на основі пошуку, створення i управління резервами ресурсів.

При проведенні ситуаційного аналізу мають бути визначені можливі стратегії вирішення проблемних ситуацій і методи їх вирішення, а також має бути сформована інформаційно-логічна схема його проведення і визначені склад, структура, програмно-інструментальні заходи і засоби ситуаційного аналізу для забезпечення підтримки прийняття рішень 3 вирішення проблемних ситуацій.

Основною задачею ситуаційного аналізу при виникненні проблемної ситуації має бути пошук можливих рішень в інтересах мінімізації (ліквідації або компенсації) втрат. При цьому послідовність дій має складатися 3 наступних етапів: прогнозування обсягів втрат; визначення необхідного обсягу додаткових засобів для вирішення проблемної ситуації; оцінювання внутрішніх ресурсів ЖЦ зразків ОВТ; вибір стратегії вирішення проблемної ситуації; реалізація стратегії вирішення проблемної ситуації. 


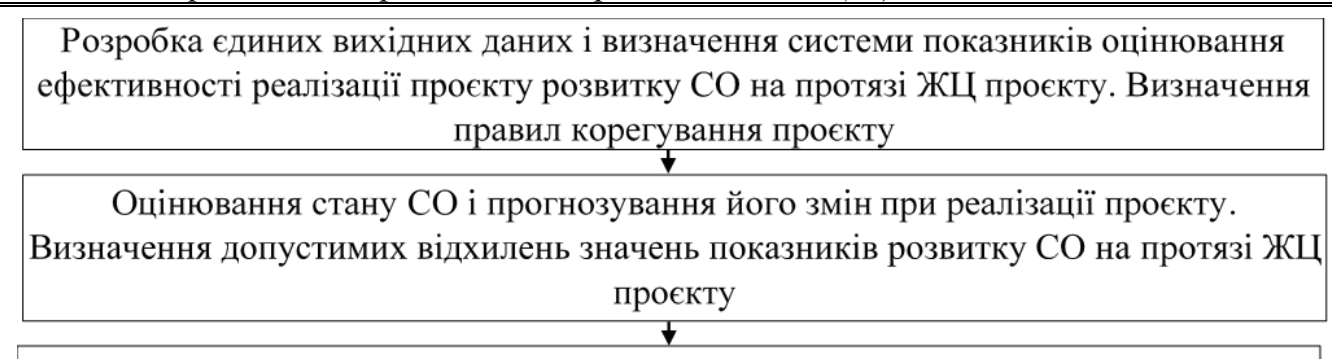

Моніторинг процесу розвитку СО, прогнозування і виявлення значень граничних відхилень показників розвитку СО при реалізації проєкту.

\begin{tabular}{|c|}
\hline $\begin{array}{c}\text { Формування ситуаційних впливів для запобігання граничним відхиленням значень } \\
\text { показників розвитку СО. Моделювання процесів розвитку підприємств ОПК, } \\
\text { забезпечення ресурсами (фінансовими, людськими, виробничими, матеріальними } \\
\text { тощо), змін безпекового середовища, формування резервів розвитку СО. }\end{array}$ \\
$\begin{array}{c}\text { Корегування плану розвитку СО. Проведення воєнно-економічного, юридичного, } \\
\text { тактико-економічного оцінювання проєкту розвитку СО. Визначення граничних } \\
\text { припустимих відхилень значень показників розвитку СО на визначений період. }\end{array}$ \\
\hline \\
Затвердження варіанту проекту розвитку СО (розділу, державної цільової \\
програми) для існуючих і прогнозованих умов розвитку СО.
\end{tabular}

Рис. 2. Етапи планування ситуаційного управління розвитком СО

Джерело: розроблено авторами.

У складі програмно-інструментальних засобів мають бути відображені:

- сучасні методи збору, обробки і аналізу даних, що дозволяють алгоритмічно відтворювати динаміку складних процесів із збереженням логічної структури і послідовності виконання заходів у часі за різними сценаріями, стратегіями і варіантами управління;

- методи моделювання процесів проведення взаємопов'язаних заходів в інтересах аналізу стратегії вирішення проблемних ситуацій, оцінювання їх наслідків і ефективності застосування.

На результатах моделювання має грунтуватись прийняття рішень 3 оперативного вирішення проблемних ситуацій, оцінювання можливих результатів і наслідків різних варіантів управлінських рішень і тощо.

Моделі проблемних ситуацій можуть бути побудовані на основі теорії орієнтованих графів (знакових, знакових виважених, функціональних знакових орграфів).

При цьому може бути здійснена формальна постановка задачі аналізу поведінки складної системи (наприклад, СО), зорієнтованої на вибір і дослідження операцій і методу перетворення моделі вихідного стану СО у модель результату.

Для цього має бути розроблений алгоритм переходу до нового (потрібного) стану СО, визначені структура і зв'язки між елементами системи, правила переходу від алгоритму до моделі у вигляді графу управління і у цілому сформована інтегральна інфо- рмаційна логічна модель переходу від одних станів CO до інших їі станів, описана мова запису алгоритмів операціями теорії множин і математичної логіки [19].

До прийняття рішення по відбору стратегії вирішення прогнозованої проблемної ситуації необхідно визначати наявний обсяг резерву ресурсів, потрібний обсяг додаткових засобів для іiі вирішення, динаміку їх змін у попередній плановий період i довгостроковий прогноз їх змін.

На процес розвитку СО можуть негативно впливати різні фактори ризику (фінансовоекономічні, науково-технічні, виробничо-технологічні, зовнішньо-політичні та інші). Реалізація факторів ризику є причиною виникнення проблемної ситуації.

Проведення ситуаційного аналізу в процесі реалізації програм і планів розвитку СО потребує наявності процедур, що забезпечують:

- визначення факторів ризику;

- оцінювання ступеню ризику виникнення проблемної ситуації при наявній ситуації динаміки змін виявлених факторів ризику;

- формування рішень 3 попередження або вирішення проблемної ситуації за аналогією або на основі синтезу відповідного сценарію управління, що побудований на основі орієнтованих графів.

Метод сценаріїв може бути використаний для прогнозування розвитку ситуації оцінювання наслідків прийняття рішень 3 попередження прогнозованої або вирішення наявної проблемної ситуації 
(використовується модель проблемної ситуації, що побудована на основі зорієнтованих графів).

Сценарії можуть бути віднесені до основних інструментів, що використовують для ефективного прийняття рішень і координації цільових дій у процесі управління станом і розвитком складних систем [5], у тому числі і СО в умовах невизначеності і неповноти вихідних даних.

Сформований сценарій має дозволити описати процес поведінки СО, розробити стратегію організації реалізації превентивних і оперативних заходів iз зміни ситуації, сформувати стратегічні і тактичні плани дій, провести якісний аналіз наслідків, а також спрогнозувати прогнозовані втрати і ризики.

Методологічною основою формування сценаріїв поведінки СО можуть бути методи структурного, матричного аналізу, апарату операційних графів тощо, що дозволяють виділяти важливі поведінкові структури системи, аналізувати їх взаємодію і СД, процес функціонування у цілому.

Можлива загальна схема формування сценаріїв приведена на рис. 3. У якості стратегії формування сценарію розвитку СО може бути використаний спосіб вибору чергової події у залежності від цілей і умов проведення заходів.

За результатом ситуаційного аналізу, при необхідності, можуть коригуватись показники державного оборонного замовлення для оперативного управління розвитком СО у програмному періоді, з урахуванням необхідності задоволення поточних потреб 3С і забезпечення розвитку їх СО для максимального наближення до відповідних показників державної цільової програми озброєння (з урахуванням поточних пріоритетів розвитку ОВТ).

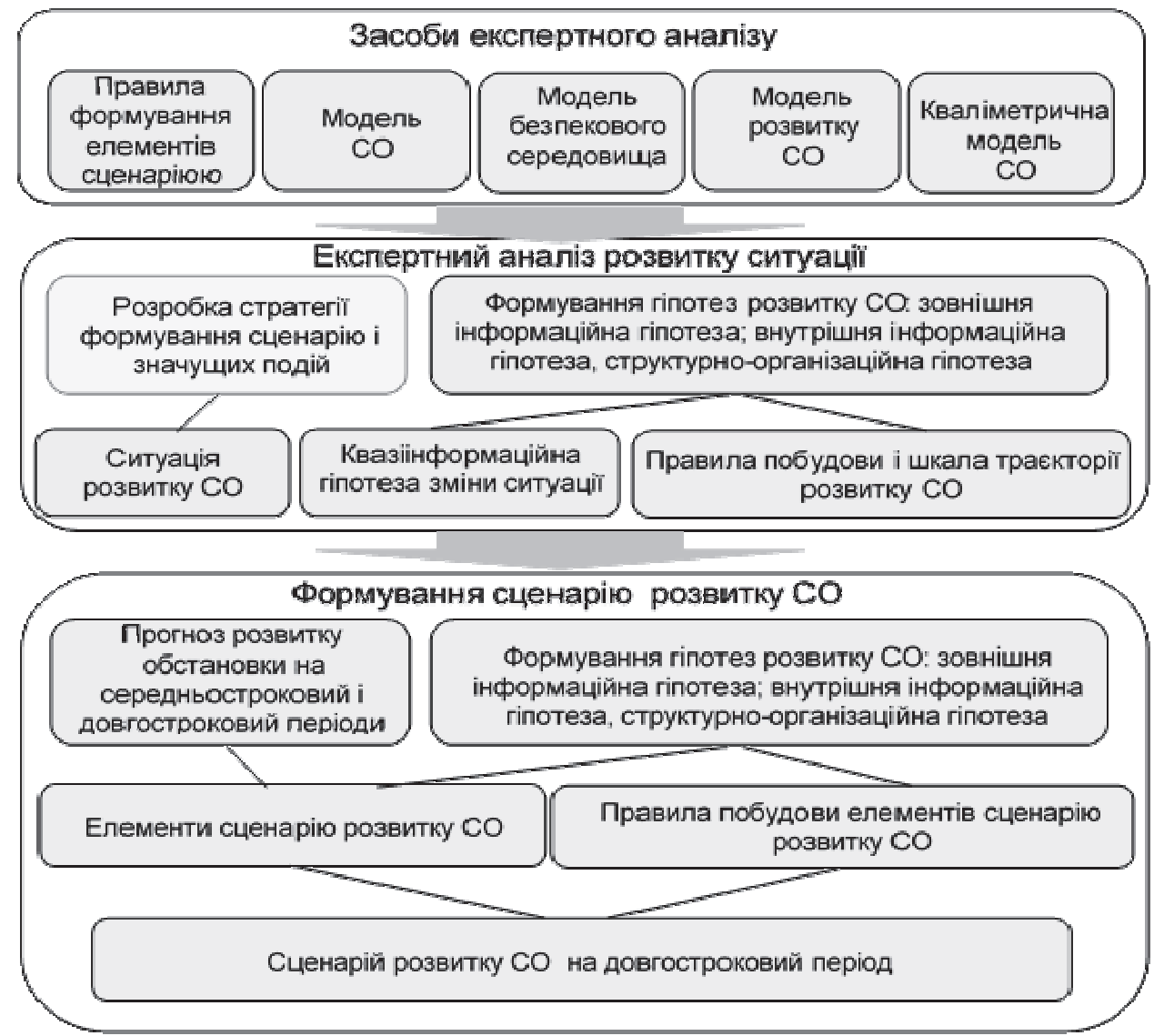

Рис. 3. Узагальнена схема формування сценарію розвитку системи озброєння (CO) Джерело: розроблено авторами.

У цілому методологія програмно-цільового планування і програмно-ситуаційного управління розвитком СО у програмному періоді грунтується на використанні ряду вельми складних і трудомістких процедур.

На стадії обгрунтування концепції розвитку і формування обліку перспективної СО доцільно використовувати спрощені методи приблизного оцінювання відносно невеликої кількості найбільш важливих узагальнених параметрів, а також застосо- вувати раціонально обмежену кількість вихідних даних. При цьому у наступних дослідженнях мають використовуватись процедури детального розгляду і обгрунтування пропозицій для включення у проекти планів розвитку ОВТ у межах державної цільової програми озброєння і державних оборонних замовлень.

Процес зміни стану СО (зміни іiі СД) тобто іiі траєкторії, у постановочній формі, може бути представлений виразом 


$$
x\left(t_{k+1}\right)=f\left(t_{k}, x\left(t_{k}\right), u\left(t_{k}\right), w\left(t_{k}\right)\right), k=0,1, \ldots, N-1,
$$

де $x$-вектор стану;

$u$ - вектор впливів управління;

$u\left(t_{k}\right) \in U\left(t_{k}\right), U\left(t_{k}\right)$ - деяка задана множина припустимих значень;

$t_{k} \in[0, T]-$ дискретні значення часу;

$N$ - задана кількість кроків;

$w\left(t_{k}\right)$ - вектор, що описує неконтрольовані впливи зовнішнього середовища на об'єкти управління;

$f\left(t_{k}, x, u, w\right)$ - вектор-функція зміни стану СО.

Мета управління - перевести СО з початкового стану $x\left(t_{0}\right)=x_{0}$ у кінцевий (потрібний) стан $x\left(t_{N}\right)$ - на кінець програмного періоду часу $t_{N}$ i забезпечити виконання умови

$$
\Gamma\left(x\left(t_{N}\right)\right) \in \Delta_{0},
$$

де $\Gamma\left(x\left(t_{N}\right)\right)$ - гіперплощина відхилень цільових показників стану СО від потрібних значень; $\Delta_{0} \subset \Gamma-$ область допустимих відхилень.

Управління розвитком СО має забезпечувати:

- динаміку реалізації ЖЦ зразків (комплексів, систем) OBT;

- структуру i динаміку фінансування стадій ЖЦ зразків ОВТ;

- структурну динаміку СО (еквівалентну за ефективністю заміну однотипних зразків ОВТ); $\mathrm{CO}$

- зміну комплектності груп ОВТ різного типу

- максимальне використання потужності ОПК.

Вирішення проблемної ситуації може бути засновано на використанні моделей у вигляді орієнтованих графів (орграфів) $G(X, E), X=\left\{x_{i}, i \leq N\right\}-$ множина вершин графу (фактори, показники станів об'єктив, що описують ситуацію і тощо), $E=\left\{e_{i j}\right\}-$ множина дуг графу $G(X, E)$ (причинні зв'язки між факторами, відхиленнями впливу фактора $x_{i}$ на фактор $x_{j}(j=1 \ldots n), n$ - кількість факторів, що мають відношення до проблемної ситуації).

При цьому до моделі має бути включений функціонал перетворення дуг $F(X, E)$, що встановлює співвідношення кожній дузі або знак, або вагу, або функцію. У результаті буде отриманий або знаковий, або зважений знаковий, або функціональний знаковий орграф.

Використання трьох типів орієнтованих графів обумовлено необхідністю врахування різного ступеню інформованості про характер зав'язків між показниками, що характеризують ситуацію.

Модель ситуації подається у вигляді знакового графу, якщо функціонал $F(X, E)$ має зміст

$$
F\left(x_{i}, x_{i j}, e_{i j}\right)=\left\{\begin{array}{c}
+1, \text { якщо зростання (падіння) } x_{i} \\
\text { веде до зростання (падіння) } x_{j} ; \\
-1, \text { якщо зростання (падіння) } x_{i} \\
\text { веде до падіння (зростання) } x_{j} .
\end{array}\right.
$$

Якщо функціонал має вигляд

$$
F\left(x_{i}, x_{i j}, e_{i j}\right)=\left\{\begin{array}{c}
+\alpha_{i j}, \text { якщо зростання (падіння) } x_{i} \\
\text { веде до зростання (падіння) } x_{j} ; \\
-\alpha_{i j}, \text { якщо зростання (падіння) } x_{i} \\
\text { веде до падіння (зростання) } x_{j},
\end{array}\right.
$$

то така модель буде подана зваженим знаковим орграфом ( $\alpha_{i j}$ - вага відповідної дуги, що характеризує силу впливу фактору $x_{i}$ на фактор $x_{j}$ ).

Якщо функціонал має вигляд $F\left(x_{i}, x_{j}, e_{i j}\right)=f_{i j}\left(x_{i}, x_{j}\right)$, то така модель буде функціональним знаковим графом.

Функціональний граф зручно представити у вигляді графу з двома типами вершин: вершини параметри (екзогенні змінні і параметри управління) і вершини - відношення (ендогенні змінні), що показують зв'язки між показниками об'єкту і зв'язки між показниками об'єктів, що взаємодіють.

Для побудови моделі проблемної ситуації на основі графів потрібно визначити:

- сукупність факторів об'єктів, що моделюється, які представляються множиною вершин $X$ графу $G(X, E)$;

- сукупність впливів факторів один на одного (відношень між факторами), які подаються множиною дуг $X$ графу $G(X, E)$;

- параметричних характеристик вершин і механізмів перетворення збурень.

Зміну значень параметрів (вершин графу) можливо інтерпретувати як перехід об'єкту з одного стану в інший.

У множині факторів моделі розвитку СО виділяються фактори, що впливають на динаміку зміни ситуації - цільові показники стану об'єкта управління. Для отримання позитивного результату розвитку $\mathrm{CO}$ необхідно забезпечити позитивну динаміку 3 урахуванням усіх вказаних факторів.

Система цільових факторів не є суперечною, якщо зміна будь-якого цільового фактору у бажаному напрямку не призводить до небажаної інтегральної зміни жодного з цільових факторів. У іншому випадку система факторів буде суперечною.

Модель проблемної ситуації буде визначена, якщо задані:

- орграф $G(X, E)$;

- функціонал $F(X, E)$;

- ситуація $s_{k}$ як сукупність зафіксованих у деякий момент часу $t_{k} \in[0, T]$ значень показників стану CO; 
- стан об'єктів, що приймають участь у процесі розвитку СО і впливають на даний процес та прийняття управлінських рішень.

При формуванні рішень з вирішення проблемної ситуації має бути встановлена принципова можливість вирішення проблемної ситуації і визначені реальні можливості іiі вирішення з урахуванням обмежень на значення параметрів управління.

Для забезпечення оперативності проведення ситуаційного аналізу необхідна завчасна розробка для кожного з об'єктів, що приймають участь у процесі розвитку СО і впливають на цей процес, розглянутих типів моделей у вигляді зорієнтованих графів і включення їх до складу програмно-інструментальних засобів, що використовуються [19].

Доцільність використання моделей проблемних ситуацій у вигляді орграфів визначається:

- їх відносною математичною простотою;

- слабкою чутливістю до точності вихідних даних і можливістю побудови адекватних моделей 3 використанням залежності як кількісного, так і якісного характеру;

- можливістю поетапного нарощування складності моделі при отриманні більш точних вихідних даних і швидкої iї адаптації за рахунок зміни топології графу і перевірки стійкості;

- можливістю використання єдиного виду моделей, що дозволяє автоматизувати процедуру пошуку причинно-наслідкових зв'язків між показниками стану, що характеризують ситуацію;

- модульною структурою моделі, що дозволяє автоматизувати процес побудови моделі на основі змістовної інформації користувачів і заздалегідь створеної бібліотеки модулів.

Використання теорії графів може забезпечувати отримання моделей, адекватних об'єкту моделювання у цензі повноти і вірності відображення інформації, яка потрібна для аналізу і синтезу структури складних систем [19]. Апарат теорії графів добре розвинутий, однак для якісного вирішення важливих прикладних задач управління розвитком СО потребує подальшого вдосконалення.

У загальному вигляді задача управління розвитком СО може бути сформульована наступним чином: визначати множину керованих впливів $u\left(t_{k}\right) \in U\left(t_{k}\right)$ таких, що для заданих початкових умов $x\left(t_{0}\right)=x_{0}$ траєкторія системи задовольняла б умовам $\Gamma\left(x\left(t_{k}\right)\right) \in \Delta_{0}$.

\section{Висновки}

Процес розвитку СО ЗС полягає у вдосконаленні тактико-техніко-економічних характеристик іiі зразків ОВТ (що складають його основу) при проведенні фундаментальних, пошукових, прикладних наукових досліджень та дослідно-конструкторських робіт, модернізації, у їх серійному виробництві. Відмінною особливістю управління розвитком $\mathrm{CO} \epsilon$ наявність великої кількості об'єктів, що взаємодіють, зв'язків між ними, впливів різних за своїм характером збурень, проявів факторів ризику, висока ступінь невизначеності й динамічності. Тому задача синтезу управління має вирішуватись за двома етапами: формування програмної (планової) траєкторії і визначення стратегічних та оперативних управлінських впливів, що реалізують програму.

Ці етапи подаються взаємопов'язаними процесами стратегічного планування i оперативного управління (регулювання) відповідно.

Планування визначається як визначення оптимальної програмної траєкторії керованої СО у відповідності з програмно-цільовим підходом на конкретному періоді часу, а регулювання - як надходження i реалізації управлінських впливів у відповідності 3 програмно-ситуаційним підходом, яке спрямоване на оперативне усунення дестабілізуючих факторів і випадкових збурень, що відхиляють процес розвитку СО від оптимальної (можливо скоригованої на попередніх етапах) програмної траєкторії.

Опис усіх основних динамічних властивостей CO і їі параметрів у формалізованому вигляді практично відобразити неможливо, тому, що складно указати функціональну залежність між станом і управлінням, тобто неможливо визначити прийнятно точно параметри управління по параметрах об'єкта управління i, як наслідок, немає можливості коректно побудувати алгоритм адаптування.

Основна причина - це складність поточних процесів, що впливають на розвиток СО.

У результаті необхідно, не створивши модель управління розвитком СО у цілому, створювати моделі планування і регулювання. При цьому хід процесу, що планується і регулюється, а також зовнішні впливи на нього неможливо точно передбачити 3 наявності випадкових факторів. У наслідок неможливо використовувати прямий підхід, що закладається в основу методів адаптації при оперативному управлінні реалізацією програм і планів розвитку СО. Це обумовлює необхідність використання методів, що дозволяють:

- прогнозувати розвиток можливої проблемної ситуації, виявляти тенденції і закономірності її розвитку;

- моделювати різні сценарії розвитку конкретної ситуації і використовувати ії вплив на стан усіх об'єктів, що приймають участь у процесі розвитку СО і впливають на даний процес, оцінювати поетапність важливості випередження негативних зміни ситуації;

- формувати альтернативне рішення 3 вирішення проблемної ситуації в інтересах випередження виникнення або мінімізації можливих втрат. 
Вказані методи складають основу ситуаційного аналізу і вирішення ситуаційних задач на основі проведення ситуаційного аналізу в інтересах своєчасного розпізнавання і вирішення проблемних ситуацій $з$ додатковим програмним управлінням елемен- тами ситуаційного типу. При цьому безумовно мають бути збережені усі основні методологічні складові програмно-цільового підходу до вирішення проблеми розвитку СО.

\section{Список літератури}

1. Методические основы системных исследований и решения проблем технического оснащения вооруженных сил государства: монография в двух книгах. Книга 1 / Б.А. Демидов, О.П. Коростылев, С.Н. Остапенко, Д.А. Гриб и др.; под ред. Б.А. Демидова и О.П. Коростылева. - К.: ИД“Стилос”, 2016. - 655 с.

2. Чепков І.Б. Теорія озброєння. Науково-технічні проблеми та завдання. Т. 6. Воєнно-економічний аналіз життєвого циклу озброєння та військової техніки: теоретико-методологічні засади: монографія / І.Б. Чепков, В.В. Зубарєв, В.К. Борохвостов. - К.: ВД Дмитра Бураго, 2018. - 475 с.

3. Чепков І.Б. Теорія озброєння. Науково-технічні проблеми та завдання. Т. 5. Воєнно-технічна політика України: формування, стан та шляхи удосконалення: монографія / І.Б. Чепков, В.В. Зубарєв, В.О. Смірнов [та ін.]. - К. : ВД Дмитра Бураго, 2017. - $448 \mathrm{c}$.

4. Борохвостов I.В. Аспекти існуючих документів оборонного планування щодо пошуку шляхів оснащення озброєннями військових формувань / І.В. Борохвостов, М.О. Білокур // Озброєння і військова техніка. - 2018. - № 4(20). C. 9-18. https://doi.org/10.34169/2414-0651.2018.4(20).9-18.

5. Методы формирования сценариев развития социально-экономических систем / В.В. Кульба, Д.А. Кононов, С.А. Косяченко, А.Н. Шубин. - М. :СИНТЕЗ, 2004. - 296 с.

6. Управление и контроль реализации социально-экономических целевых программ / Под ред. В.В. Кульба и С.С. Ковалевского. - М.: Книжный дом “ЛИБРОКОМ”, 2009. - 400 с.

7. Проблематика теорії і практики управління структурною динамікою складних багатоструктурних систем військового призначення в умовах обстановки, що динамічно змінюється в районі бойових дій / Б.О. Демідов, М.І. Луханін, О.Ф. Велічко, Д.А. Гриб, О.О. Хмелевська // Озброєння і військова техніка. - 2019. - № 3(23). - С. $26-39$.

8. Поспелов Д.А. Ситуационное управление: теория и практика / Д.А.Поспелов. - М.: Наука. - Гл. ред. физ.-мат. лит., 1986. -288 с.

9. Методы и модели ситуационного анализа при управлении развитием сложных технических систем / И.И. Глушков, Н.В. Латышев, В.Н. Минаев, С.Н. Остапенко. - Тверь, 2012. - 624 с.

10. Бурков В.Н. Введение в теорию управления организационными системами / В.Н. Бурков, Н.А. Коргин, Д.А. Новиков; под ред. Д.А. Новикова. - М.: Книжный дом “ЛИБРОКОМ”, 2009.- 264 с.

11. Коваленко O.С. Ситуаційне управління як проектна діяльність / О.С. Коваленко // Теорія і практика: Збірник доповідей науково-практичної конференції з міжнародною участю. - 2017. - С. 28-31.

12. Коваленко О.С. Застосування антологій в системах ситуаційного управління / O.Є. Коваленко // Сучасні проблеми інформатики в управлінні, економіці, освіті та подоланні наслідків Чорнобильської катастрофи: [матеріали XV Міжнародного наукового семінару, Київ - оз. Світязь, 4-8 липня 2016 року]. - К.: Національна академія управління, 2016. - C. 84-89.

13. Методика нечіткого оцінювання для систем підтримки прийняття проектних рішень на етапах створення зразків озброєння і військової техніки / О.О. Головін, М.В. Зірка, Н.П. Кадет, Н.М. Коцюруба // Озброєння та військова техніка. - 2019. - № 3(23). - С. 99-109.

14. Шаріпова О.С. Визначення об'єктів гармонізації з позицій процесного, ситуаційного та проектного управління / О.С. Шаріпова // Управління проектами та розвиток виробництва: Зб. наук. пр. - Луганськ: вид-во СНУ ім. В.Даля, 2013. - № 2(46). - C. 12-16.

15. Методичні рекомендації з управління проектами. - Київ: МО України, 2019 - 51 с. - Режим доступу: https://www.mil.gov.ua/content/oboron_plans/Metod_recomendacii_z_ypravlinnia_proektamy.pdf.

16. Порівняльний аналіз систем оборонного планування в США та в Україні / І.Б. Чепков, В.В. Сотник, І.В. Борохвостов, М.В. Бондарчук, М.О. Білокур // Озброєння та військова техніка. - 2019. - № 3(23). - С. 3-15.

17. Теорія озброєння. Науково-технічні проблеми та завдання. Т.4. Воєннотехнічна політика провідних країн світу: монографія / І.Б. Чепков, В.В. Зубарєв, В.О. Смірнов [та ін.]. - К. : Видавничий дім Дмитра Бураго, 2016. -388 с.

18. Головін О.О. Застосування методології трансдисциплінарних онтологій в інформаційно-аналітичній системі підтримки процесів оснащення озброєнням та військовою технікою / О.О. Головін // Системи озброєння і військова техніка. - 2019. - № 3(59). - С. 17-24. https://doi.org/10.30748/soivt.2019.59.02.

19. Овчинников В.А. Графы в задачах анализа и синтеза структур сложных систем / В.А. Овчинников. - М.: МГТУ им. Н.Э. Баумана, 2014. - 423 с.

Надійшла до редколегії 18.11.2020

Схвалена до друку 15.12.2020

\section{Відомості про авторів:}

\section{Гриб Дмитро Анатолійович}

кандидат військових наук доцент головний науковий співробітник Харківського національного університету Повітряних Сил ім. І. Кожедуба, Харків, Україна

https://orcid.org/0000-0001-8478-978X

\section{Information about the authors:}

\section{Dmitry Grib}

Candidate of Military Sciences Associate Professor

Chief Research

of Ivan Kozhedub Kharkiv National

Air Force University,

Kharkiv, Ukraine

https://orcid.org/0000-0001-8478-978X 
Демідов Борис Олексійович

доктор технічних наук професор

провідний науковий співробітник

Харківського національного університету

Повітряних Сил ім. І. Кожедуба,

Харків, Україна

https://orcid.org/0000-0003-1728-6925

Хмелевська Ольга Олександрівна

кандидат технічних наук старший науковий співробітник провідний науковий співробітник

Харківського національного університету

Повітряних Сил ім. І. Кожедуба,

Харків, Україна

https://orcid.org/0000-0001-9018-5552

\section{Хмелевський Сергій Іванович}

кандидат технічних наук старший науковий співробітник начальник кафедри

Харківського національного університету

Повітряних Сил ім. І. Кожедуба,

Харків, Україна

https://orcid.org/0000-0001-6216-3006
Boris Demidov

Doctor of Technical Sciences Professor

Lead Research

of Ivan Kozhedub Kharkiv National

Air Force University,

Kharkiv, Ukraine

https://orcid.org/0000-0003-1728-6925

Olga Khmelevska

Candidate of Technical Sciences Senior Research

Lead Research

of Ivan Kozhedub Kharkiv National

Air Force University,

Kharkiv, Ukraine

https://orcid.org/0000-0001-9018-5552

Serhii Khmelevskiy

Candidate of Technical Sciences Senior Research

Head of Department

of Ivan Kogedub Kharkiv National

Air Force University,

Kharkiv, Ukraine

https://orcid.org/0000-0001-6216-3006

\title{
МЕТОДИЧЕСКИЕ И ОРГАНИЗАЦИОННЫЕ ОСНОВЫ ПРОГРАММНО-СИТУАЦИОННОГО УПРАВЛЕНИЯ РАЗВИТИЕМ СИСТЕМЫ ВООРУЖЕНИЯ ВООРУЖЕННЫХ СИЛ
}

\author{
Д.А. Гриб, Б.А. Демидов, О.А. Хмелевская, С.И. Хмелевский
}

В статье рассматриваются проблемные вопросы, связанные с использованием приниипов и положений программно-ситуационного подхода к решению задач управления развитием системы вооружения вооруженных сил государства в программном периоде времени. Основное внимание уделяется использованию стратегического программно-целевого планирования и программно-ситуачионного подхода к оперативному управлению разрешением проблемных ситуаций 6 условиях неопределенности и недостаточности исходных данных, необходимых для адекватного и адаптивного реагирования на изменения внешней среды (оперативно-стратегической, военно-экономической, производственнотехнологической, другой обстановки). Проводится анализ известных подходов к определению проблемных ситуаций развития системы вооружения на долгосрочный период и определяется необходимость формирования сиенариев ее развития. Отмечается важность применения проектного подхода для объединения процессов ситуачионного и процессного управления. Анализируются различия программно-ситуачионного и программно-иелевого подхода для оперативного планирования мероприятий по противодействию негативным тенденциям изменения системы вооружения. Указывается на иелесообразность использования ориентированных графов для создания моделей проблемных ситуаций развития системы вооружения и отдельных ее составляющих на долгосрочный период. Такие модели должны обладать необходимой полнотой и верностью отображения информачии, которая нужна для анализа проиессов развития негативных ситуачий и принятия органами управления верных управленческих решений по противодействию этому развитию. Предложены методы, которые позволяют: прогнозировать развитие возможной проблемной ситуачии, определять тенденичи и закономерности её развития, формулировать альтернативные варианты решения проблемной ситуачии в интересах её опережения и минимизачии возможных потерь.

Ключевые слова: система вооружения вооруженных сил, проблемная ситуачия, ситуационный анализ, модель проблемной ситуации, сценарий развития проблемной ситуации, резервы ресурсов.

\section{METHODOLOGICAL AND ORGANIZATIONAL BASES OF PROGRAMMED AND SITUATIONAL CONTROL OF THE ARMED FORCES ARMAMENTS}

D. Grib, B. Demidov, O. Khmelevska, S. Khmelevskiy

The article discusses issues related to the use of the principles and factors of the programmed and situational approach to the tasks of managing the development of the armed forces armaments of a State during the programming period. Emphasis is placed on the use of strategic, programmed and targeted planning and a programmed and situational approach to the operational management of problem situations in an environment of uncertainty and insufficient baseline data, necessary for an adequate and adaptive response to changes in the external environment (strategic, military and economic, engineering and manufacturing other environment). An analysis is being made of known approaches to identifying problem situations in the development of a weapons system over the long term and the need to develop scenarios for its development. The importance of using a project approach to integrate situation and process management processes is noted. The differences between the programmed and situational and the programmed and targeted approach are analysed for the operational planning of activities to counteract negative trends in the changing weapons system. The use of directed graphs to create models of problem situations in the development of the weapons system and its individual components for the long term is indicated. Such models should have the necessary completeness and accuracy to display the information needed to analyse the processes of developing negative situations and to make the correct management decisions by the administration to counteract this development.

Keywords: armed forces armaments system, problem situation, situational analysis, model of the problem situation, scenario for the development of a problem situation, resource reserves. 